\title{
Three new species and new records of African Psammoecus Latreille (Coleoptera, Silvanidae)
}

\author{
Michael KARNER \\ Voluntary Scientist, Sektion Entomologie I, Forschungsinstitut Senckenberg, \\ Senckenberganlage 25, D-60325 Frankfurt am Main, Germany. \\ E-mail: michael.karner@senckenberg.de \\ urn:1sid:zoobank.org:author:48E64F07-CDD3-4B4B-9C9A-24CBFCBBCB3D
}

\begin{abstract}
Three new African species of Psammoecus Latreille, 1829 are described: Psammoecus nyakabuyensis sp. nov., Psammoecus procerus sp. nov. and Psammoecus sinuaticollis sp. nov. New distribution data and a revised identification key for African Psammoecus are given.
\end{abstract}

Key words. Africa, Silvanidae, Psammoecus, taxonomy, distribution

Karner M. 2014. Three new species and new records of African Psammoecus Latreille (Coleoptera, Silvanidae). European Journal of Taxonomy 89: 1-18. http://dx.doi.org/10.5852/ejt.2014.89

\section{Introduction}

In the course of work that followed a revision of African Psammoecus Latreille, 1829, predominantly based on material from the Tervuren Museum (Karner 2012), 237 specimens from several other collections were examined. Since little is known about the distribution of African Psammoecus, the present paper makes the new faunistic data available. The material also contained three new species that are described here.

\section{Notes on some characters}

The shape of the temples shows considerable differences between species. Temples may be well developed and wide, or they may be narrowed very steeply. To provide a measure for the degree of narrowing, the angle between the temple and the longitudinal axis of the head can be used (see Fig. 1). The resulting value is called the 'temple angle', it is given as an angular degree.

The pubescence on head and pronotum is composed of mostly semierect setae; the elytral pubescence consists of strial and interstrial setae. In all African species studied by the author so far, the setae are directed anteriorly on the head and pronotum, and posteriorly on the elytra.

Near the anterior angles of the pronotum, small seta-bearing denticles or groups of denticles are present in all African species, sometimes reduced to minute structures. A posterior denticle near the posterior angle is present in most species. Frequently, also the lateral pronotal margins bear teeth of different size, shape and pattern. Teeth along the lateral pronotal margin - located between anterior and posterior denticles - are numbered in roman numerals, starting anteriorly, and are named 'T I', 'T II', etc. Setae 
originating from these teeth are more or less damaged in most museum specimens; they are extremely fragile and prone to being damaged during collection of specimens in the field. Even in well conserved material, specimens with undamaged setation (such as shown in Fig. 2A) are rarely observed. While the cleaning of specimens for photography would be desirable from an aesthetic point of view, any attempt to remove dirt, dust particles, etc. was found to severely damage the pubescence even in well softened specimens. For that reason, it was not attempted to clean specimens, even though the aesthetics of photographs was somewhat compromised.

\section{Material and Methods}

Measurements were taken as follows:

Length: from apical margin of clypeus to apex of elytra

Head width: across eyes

Head length: from apical margin of clypeus to imaginary line between hind margins of eyes

Eye length: from anterior to posterior margin

Antennal length: from base of $1^{\text {st }}$ antennomere to apex of $11^{\text {th }}$ antennomere

Pronotal width: across maximum width, excluding spines

Pronotal length: from anterior to posterior margin

Elytral width: across maximum joint width

Elytral length: along suture including scutellum

Relative proportions (lengths) of antennomere are listed from $1^{\text {st }}$ to $11^{\text {th }}$ antennomere. Microsculpture was assessed at $80 \mathrm{x}$ magnification.

For dissection of genitalia, the method described by Karner (2012) was used. For photography, the isolated aedeagus was placed in a warm drop of Kaiser's glycerol gelatin (Carl Roth $\mathrm{GmbH}$ ) to enable precise orientation. After study, structures were embedded in dimethylhydantoin formaldehyde resin (Steedman 1958) on a cellulose acetate label and attached to the pin of the respective specimen.

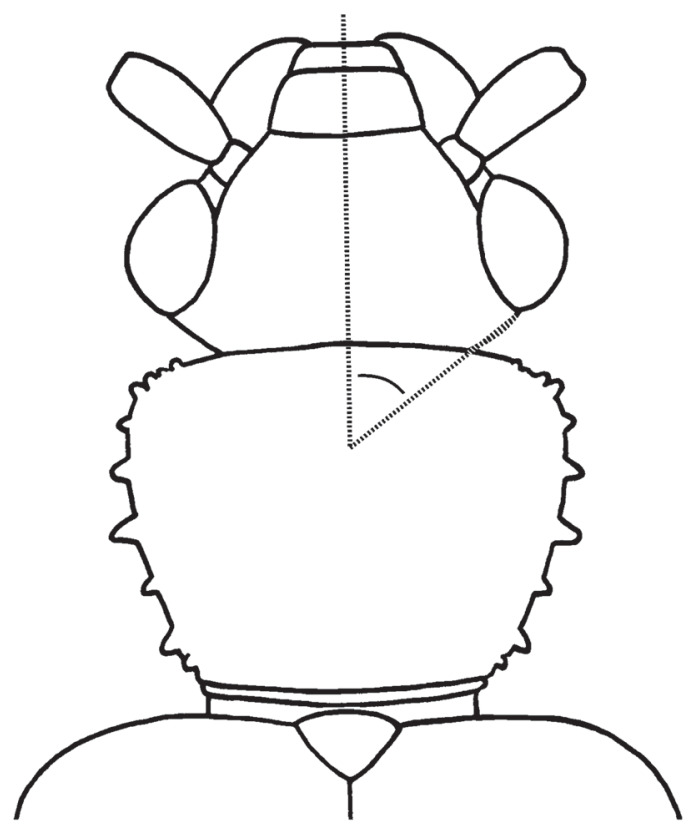

Fig. 1. Scheme for temple angle measurement. 
Photographs were taken with a Canon EOS 650D digital camera attached to an Olympus SZX16 stereo microscope and photographs of genitalia were taken with a Canon EOS 650D digital camera attached to an Olympus $\mathrm{CH}$ microscope. Images and image layers were processed with Zerene Stacker (Version 1.04 Build T201311272225), Adobe Lightroom 5.3 and GIMP (Version 2.8.0) software.

All label data are given verbatim for type material. The labels are cited beginning with the uppermost one; the respective lines are separated by 'l'. Comments on label colors, label shapes, etc. regarding the respective specimen are included in square brackets. Locality and collection data for other material examined are condensed, sorted alphabetically by country.

Specimens from the following collections were studied:

BMNH $=$ The Natural History Museum, London

HNHM $=$ Termeszettudomanyi Muzeum, Budapest

MKF $=$ Michael Karner, Frankfurt am Main (later in SMF)

MHNG $=$ Muséum d'Histoire Naturelle, Geneva

SMF $=$ Forschungsinstitut Senckenberg, Frankfurt am Main

TMSA $=$ Ditsong National Museum of Natural History, Pretoria

$\mathrm{ZMHB}=$ Museum für Naturkunde der Humboldt-Universität, Berlin

\section{Results}

\section{Taxonomy}

Class Hexapoda Blainville, 1816

Order Coleoptera Linnaeus, 1758

Family Silvanidae Kirby, 1837

Subfamily Brontinae Erichson, 1845

Tribe Telephanini LeConte, 1861

Genus Psammoecus Latreille, 1829

Psammoecus nyakabuyensis sp. nov.

Fig. $2 \mathrm{~A}-\mathrm{G}$

urn:1sid:zoobank.org:act:FEA38F3A-722B-45B0-B336-1C885FDB7262

\section{Diagnosis}

The following combination of character states is diagnostic for this species: $1^{\text {st }}$ antennomere 2.1 times as long as $2^{\text {nd }}$ antennomere; maximum pronotal width near middle; lateral margins of pronotum with distinct, triangular teeth with wide bases, anterior angle of pronotum with distinct denticle; elytral striae narrower than interstices; interstices of lateral elytral striae with very small tubercles; median lobe of aedeagus wide, abruptly narrowed towards apex; parameres distinctly separated from basal piece.

\section{Differential diagnosis}

Psammoecus nyakabuyensis sp. nov. resembles P. luchti Karner, 2012 and can be distinguished by its narrower elytral striae; it differs from P. luchti and all other African Psammoecus also by the shape of the male genitalia.

\section{Etymology}

The specific epithet is derived from the name of the locality where the type material was collected. 

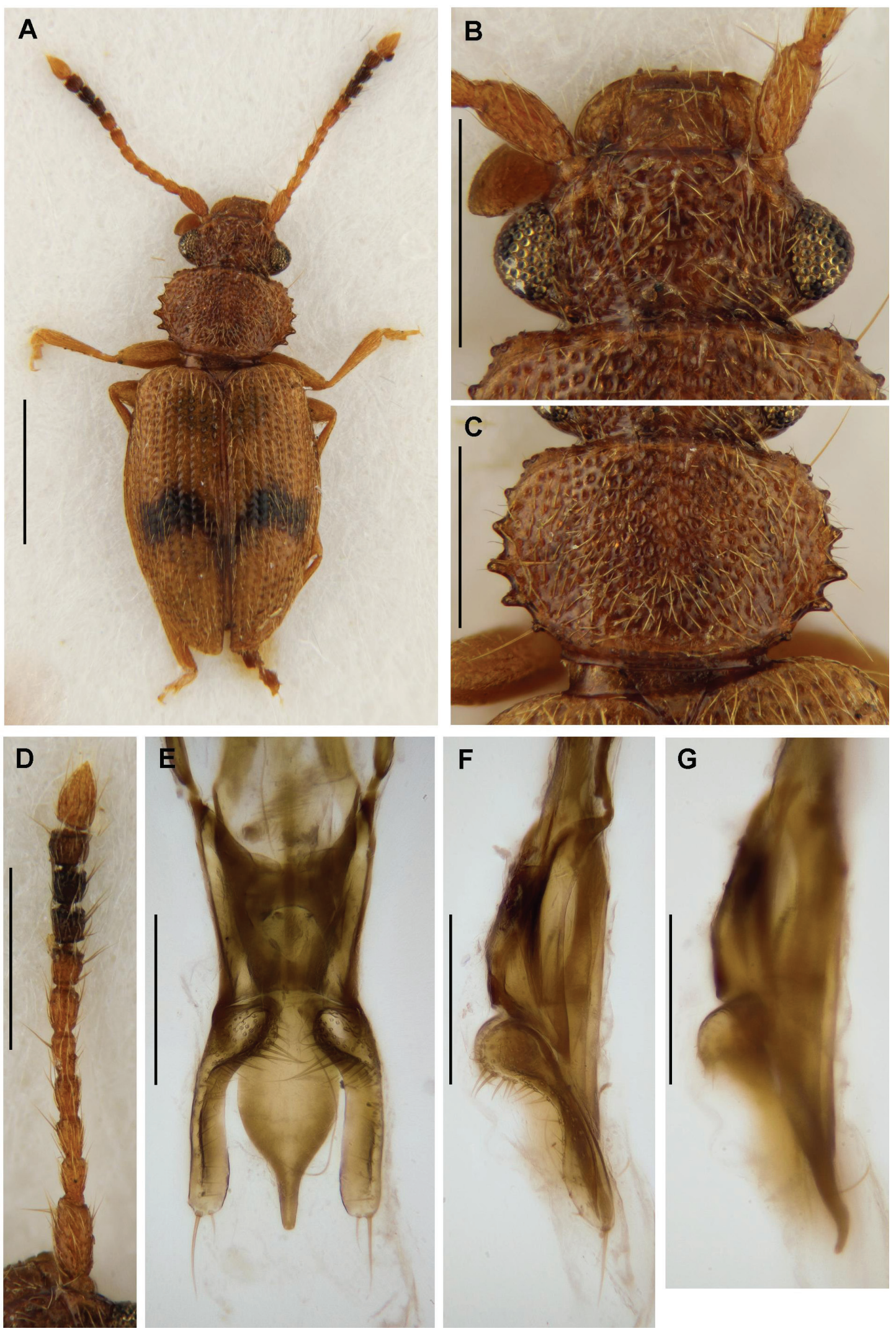

Fig. 2. Psammoecus nyakabuyensis sp. nov., holotype. A. Habitus. B. Head. C. Pronotum. D. Right antenna. E. Aedeagus, ventral view. F. Paramere, lateral view. G. Median lobe, lateral view. Scale lines: $\mathrm{A}=1.0 \mathrm{~mm}, \mathrm{~B}-\mathrm{D}=0.5 \mathrm{~mm}, \mathrm{E}-\mathrm{G}=0.2 \mathrm{~mm}$. 


\section{Material examined}

\section{Holotype}

đ ‘Afrika RUANDA | Pref. Cyangugu | Umg. Nyakabuye | 17.2.1985 [17 Feb. 1985] | leg. H. Mühle’ (SMF).

\section{Paratypes}

2 9 ㅇ ‘Afrika RUANDA | Pref. Cyangugu | Umg. Nyakabuye | 16.10.1984 [16 Oct. 1984] | leg. H. Mühle’ (MKF). 1 đ 'Afrika/Rwanda | Bez. Cyangugu | Urw.v.Nyakabuye | 1700-1900 m | leg.V.u.C.Brachat | 14.-27.2.1985 [14-27 Feb. 1985]’ (MKF).

\section{Description of holotype}

Body (as in Fig. 2A). Oval, castaneous, total length $3.05 \mathrm{~mm}$. Elytra with transverse, dark brown maculae near middle. Antennomeres 8-10 dark brown, 11 bright testaceous.

HEAD (as in Fig. 2B). Eyes large, prominent; temples distinctly narrowed immediately behind eyes, temple angle $65^{\circ}$; head width $0.79 \mathrm{~mm}$, length $0.46 \mathrm{~mm}$. Puncturation on vertex coarse, punctures about 1.25 times as large as an eye facet diameter, contiguous laterally, well separated medially; pubescence composed of short, semierect setae, directed anteriorly; microsculpture absent. Longitudinal impressions on vertex short and shallow, curved outwardly, attaining 1/5 of eyes. Eyes $0.21 \mathrm{~mm}$ long, distance of inner margins $0.50 \mathrm{~mm}$. Temples immediately narrowed behind eyes, slightly curved. Antennae
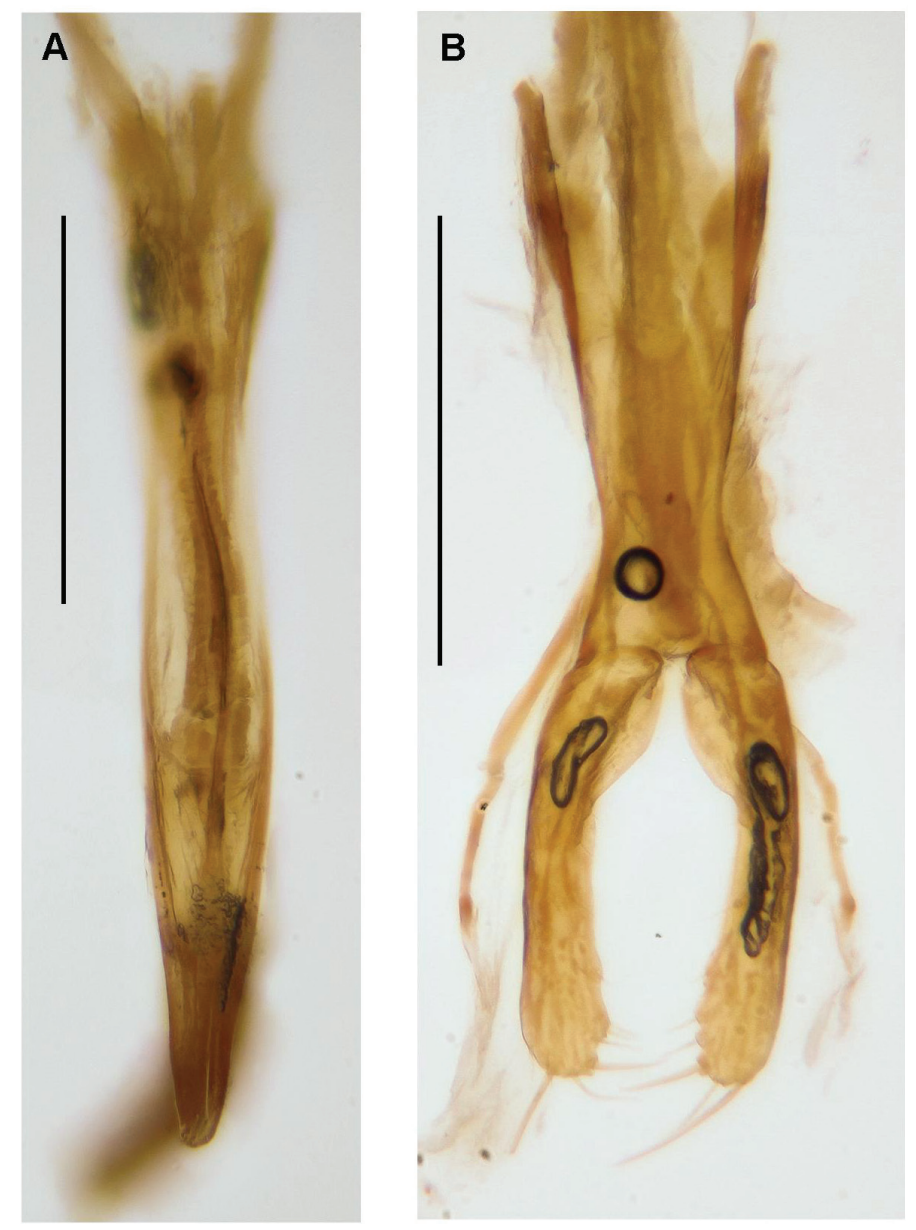

Fig. 3. Psammoecus luchti Karner, 2012. A. Median lobe. B. Parameres. Scale lines $=0.2 \mathrm{~mm}$. 
comparatively stout, $1.44 \mathrm{~mm}$ long; antennomere proportions: $2.5: 1.2: 1.3: 1.3: 1.3: 1.3: 1.0: 1.0$ : $1.0: 1.0: 2.0$ (Fig. 2D).

Pronotum (as in Fig. 2C). Wider than head, lateral margins strongly curved, widest at middle, surface slightly impressed near posterior angles and basis; width $0.90 \mathrm{~mm}$, length $0.64 \mathrm{~mm}$. Anterior angles with small denticles; lateral margins with four wide teeth; T I very small, only slightly larger than anterior denticles, T II about twice as big as T I, T III and T IV of same size, about twice as big as T II; posterior angle with small denticle, located in the middle between T IV and posterior margin. Puncturation and pubescence on pronotal disk as on vertex; punctures more sparse near posterior angles and basis. Microsculpture absent.

ElYTRA. Oval, widest at middle, length $2.00 \mathrm{~mm}$, combined width $1.35 \mathrm{~mm}$. Rows of punctures on disc somewhat narrower than interstices; pubescence composed of short semierect setae, strial and interstrial setae of identical length; microsculpture absent.

Male genitalia (as in Fig. 2E-G). Parameres wide, moderately narrowed towards apex, bearing numerous long setae near mesal face of basis, shorter setae on ventral edge, and a very long and a short seta at apex; in lateral view strongly narrowed near middle, and widened, somewhat spoon-shaped, towards apex. Median lobe wide, narrowed towards apex in a basally convex, apically concave curve to form a narrow, almost parallel-sided protrusion with blunt tip; S-curved towards apex in lateral view.

\section{Variation}

The paratypes vary in body length from 2.92 to $3.30 \mathrm{~mm}$.

\section{Remarks}

Even though Psammoecus nyakabuyensis sp. nov. resembles $P$. luchti in general appearance, the structures of the male genitalia differ very much (Fig. 3A-B shows the genitalia of $P$. luchti for comparison). A close relation of these two species is therefore very unlikely.

\section{Psammoecus procerus sp. nov.}

Fig. $4 \mathrm{~A}-\mathrm{G}$

urn:1sid:zoobank.org:act:C44995A0-A3D4-4C4A-A80A-F45ED4CD4202

\section{Diagnosis}

The following combination of character states is diagnostic for this species: lateral margins of pronotum with very small teeth; antennomeres slender; $1^{\text {st }}$ antennomere 3 times as long as $2^{\text {nd }}$; microsculpture on vertex and disk of pronotum distinct, reticulate; median lobe of aedeagus slender; parameres long, slender.

\section{Differential diagnosis}

This species is most similar to $P$. grandis Grouvelle, 1908; it can be distinguished by the shape of the antennomeres and male genitalia. It differs from all other African Psammoecus by its large size.

\section{Etymology}

The specific epithet is the Latin word for "slender". 

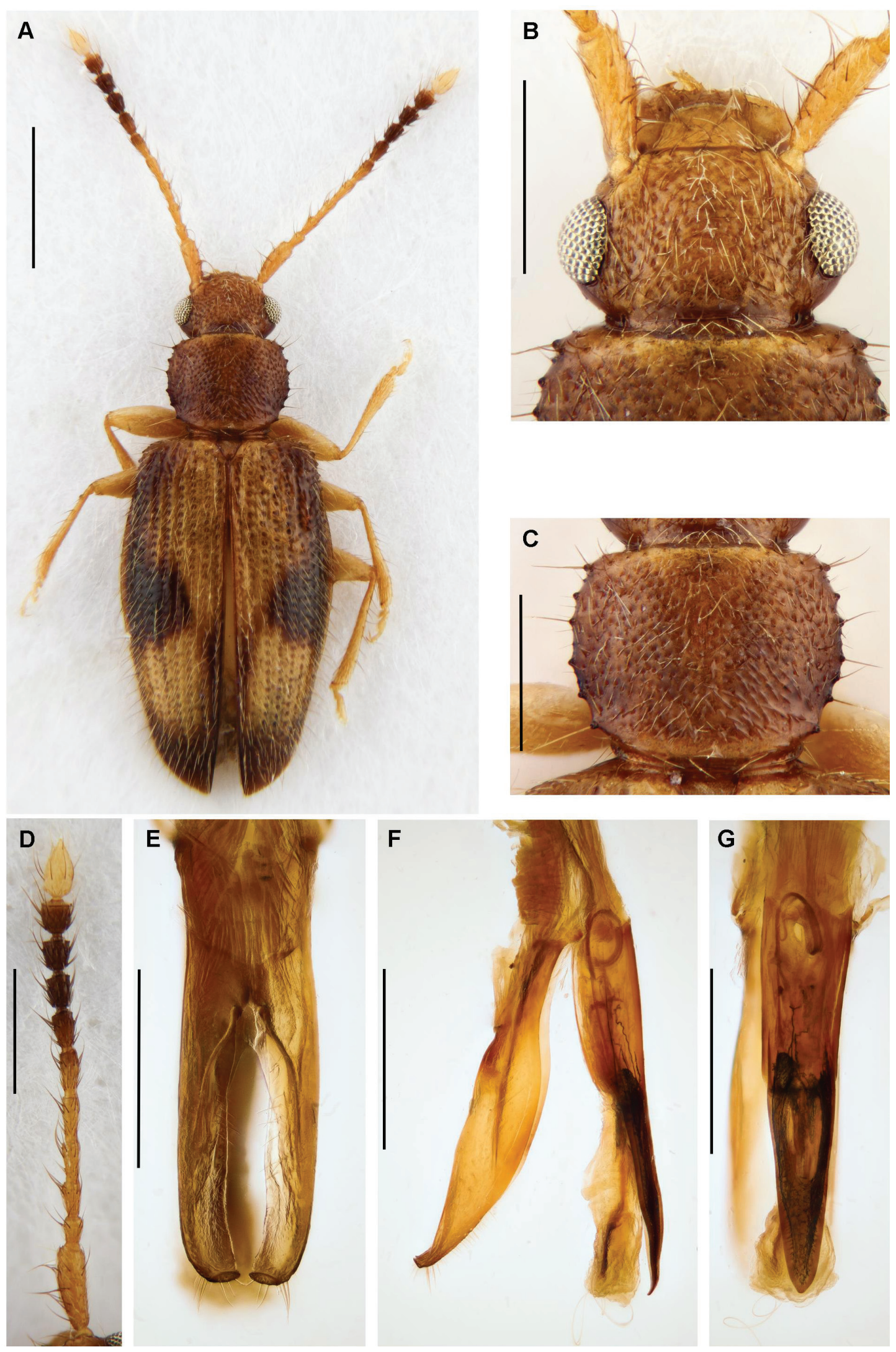

Fig. 4. Psammoecus procerus sp. nov., holotype. A. Habitus. B. Head. C. Pronotum. D. Right antenna. E-G. Aedeagus $(\mathrm{E}=$ ventral, $\mathrm{F}=$ lateral, $\mathrm{G}=$ dorsal view $)$. Scale lines: $\mathrm{A}=1.0 \mathrm{~mm}, \mathrm{~B}-\mathrm{G}=0.5 \mathrm{~mm}$. 


\section{Material examined}

Holotype

đ̊ ‘SAO TOMÉ | Bom Successo, | ECOFAC compound | 7.-13.vi.1999 [7-13 Jun. 1999]', ‘A. Polaszek | BMNH 2005-138' (BMNH).

\section{Paratypes}

4 우, with same data as holotype (3 BMNH, $1 \mathrm{MKF})$.

\section{Description of holotype}

Body (as in Fig. 4A). Elongate, slender, total length $3.6 \mathrm{~mm}$. Elytra testaceous; humeral swelling and lateral margin dark brown, the dark coloration extended to a broad macula near the middle; apical half of suture and apex dark brown. Head and pronotum reddish brown; lateral margins of pronotum a little darker; anterior and posterior margins of pronotum lighter brown. Antennae testaceous, apex of antennomere 6 and antennomeres 7-10 darkened, antennomere 11 yellowish white. Legs yellow.

HEAD (as in Fig. 4B). Eyes moderately rounded, temples well defined and curved, moderately narrowed behind eyes, temple angle $44^{\circ}$; head width $0.78 \mathrm{~mm}$, length $0.46 \mathrm{~mm}$. Puncturation on vertex irregular; punctures almost as large as an eye facet diameter, sometimes contiguous, sometimes leaving spaces the size of their diameter. Pubescence composed of long, semi-erect setae, directed anteriorly; microsculpture on apical part of vertex distinct, reticulate, on basal part of vertex very shallow. Longitudinal impressions on vertex short, slightly curved, barely attaining eye level. Eyes $0.23 \mathrm{~mm}$ long, distance of inner margins $0.52 \mathrm{~mm}$. Antennae slender, attaining almost middle of elytra, $1.98 \mathrm{~mm}$ long; antennomere proportions: $3.0: 1.0: 1.3: 1.5: 1.7: 1.5: 1.4: 1.3: 1.1: 1.1: 2.1$ (Fig. 4 D).
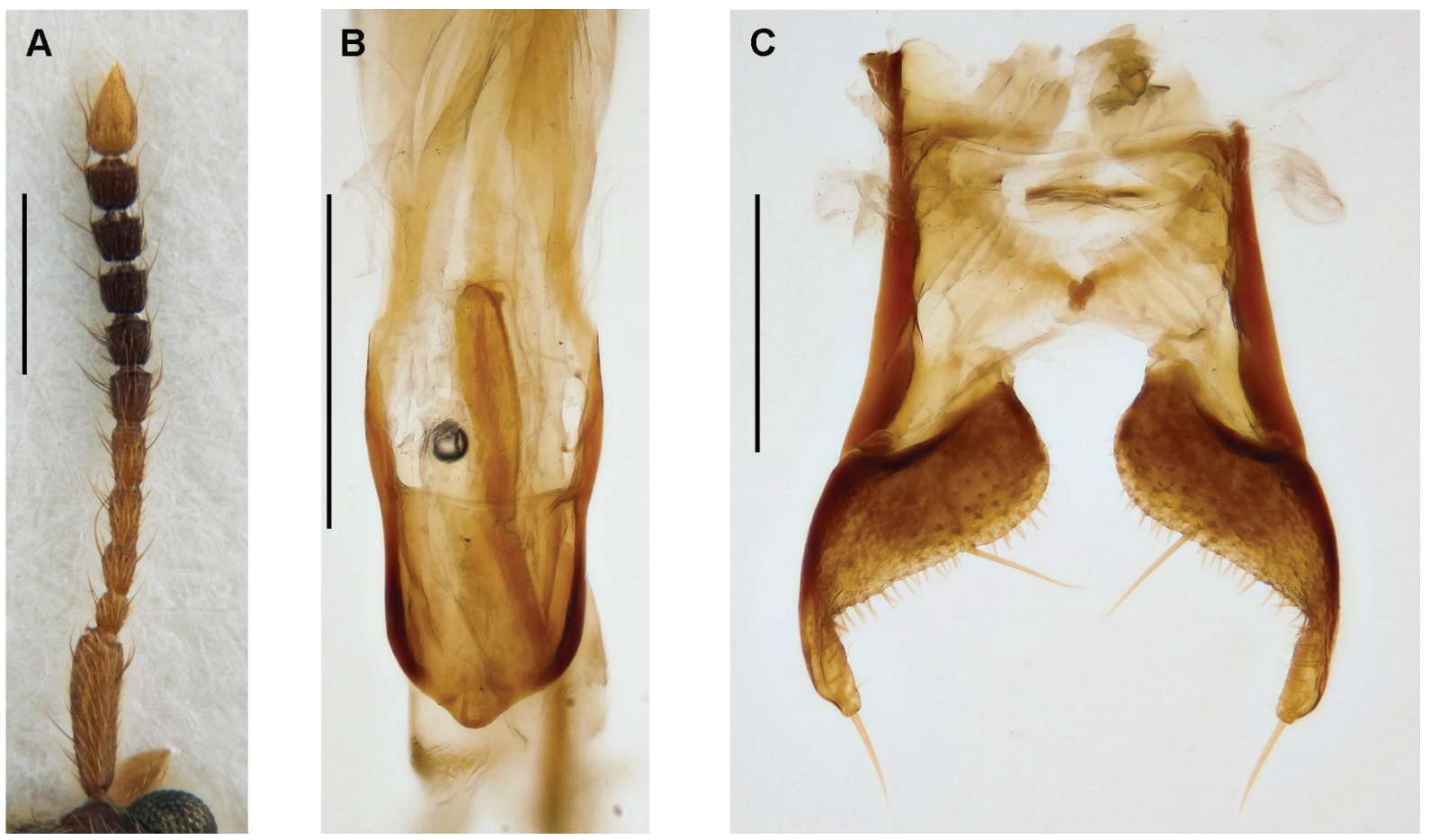

Fig. 5. Psammoecus grandis Grouvelle, 1908. A. Right antenna. B. Median lobe. C. Parameres. Scale lines $=0.5 \mathrm{~mm}$. 
Pronotum (as in Fig. 4C). About 1.1 times as wide as head; moderately wider than long; width 0.86 $\mathrm{mm}$, length $0.73 \mathrm{~mm}$. Area close to the posterior angles slightly depressed. Anterior angles separated from the disk by a slightly raised ridge; the small anterolateral space separated by that ridge without microsculpture, bearing 3 short teeth. Left lateral margin with 4, right margin with 5 very short teeth, posterior angle marked by a tooth of same size as lateral teeth. Puncture size on pronotal disk as on vertex, puncturation less dense. Pubescence as on vertex. Microsculpture distinct, reticulate.

ELYTRA. Long and slender, 3.3x as long as pronotum, widest just in front of middle, length $2.44 \mathrm{~mm}$, combined width $1.40 \mathrm{~mm}$. Elytral disk with a flat depression between first and second third. Rows of punctures on disk about half as wide as interstices; pubescence composed of long, semierect setae; strial setae about $1 / 3$ shorter than interstrial setae; microsculpture restricted to areas near origin of setae, reticulate.

Male genitalia (as in Fig. 4E-G). Parameres in ventral view wide, elongate, lateral face parallel, curved medially towards the apex; in lateral view lancet-shaped, almost straight ventrally and curved dorsally, apical third of dorsal face with short setae, tip bent ventrally. Median lobe slender, evenly narrowed toward apex in dorsal view; in lateral view wide to about the middle, narrowed to a parallel-sided section of about 2/5 its length; apical 1/6 narrowed, dorsal face curved in an S-shape, tip bent ventrally.

\section{Variation}

The paratypes vary in body length from 3.60 to $3.92 \mathrm{~mm}$.

\section{Remarks}

The general appearance and the unusual structure of the male genitalia make this species a very untypical member of the genus Psammoecus. Its habitus closely resembles that of $P$. grandis Grouvelle, 1908, but the antennae as well as the male genitalia of $P$. grandis have an exceedingly different structure (see Fig. $5 \mathrm{~A}-\mathrm{C})$.

Psammoecus sinuaticollis sp. nov.

Fig. 6A-F

urn:1sid:zoobank.org:act:A9A3CA72-0F29-490D-8364-8F6DA42FE3A7

\section{Diagnosis}

The following combination of character states is diagnostic for this species: lateral margins of pronotum with distinct teeth; $1^{\text {st }}$ antennomere 2.3 times as long as $2^{\text {nd }}$ antennomere; interstices of lateral elytral striae with very small tubercles; anterior angle of pronotum without denticle.

\section{Differential diagnosis}

This species differs from all other African Psammoecus by lacking the posterior pronotal denticle and by the shape of the male genitalia.

\section{Etymology}

The specific epithet refers to the rounded shape of the pronotum.

\section{Material examined}

\section{Holotype}

ô 'GHANA: Ashanti region | Jamasi | 289 m, N 658 - E 128 | Dr. S. ENDRÖDY-YOUNGA', 'Nr.310 | beaten | 23.II.1969 [23 Feb. 1969]' (HNHM). 

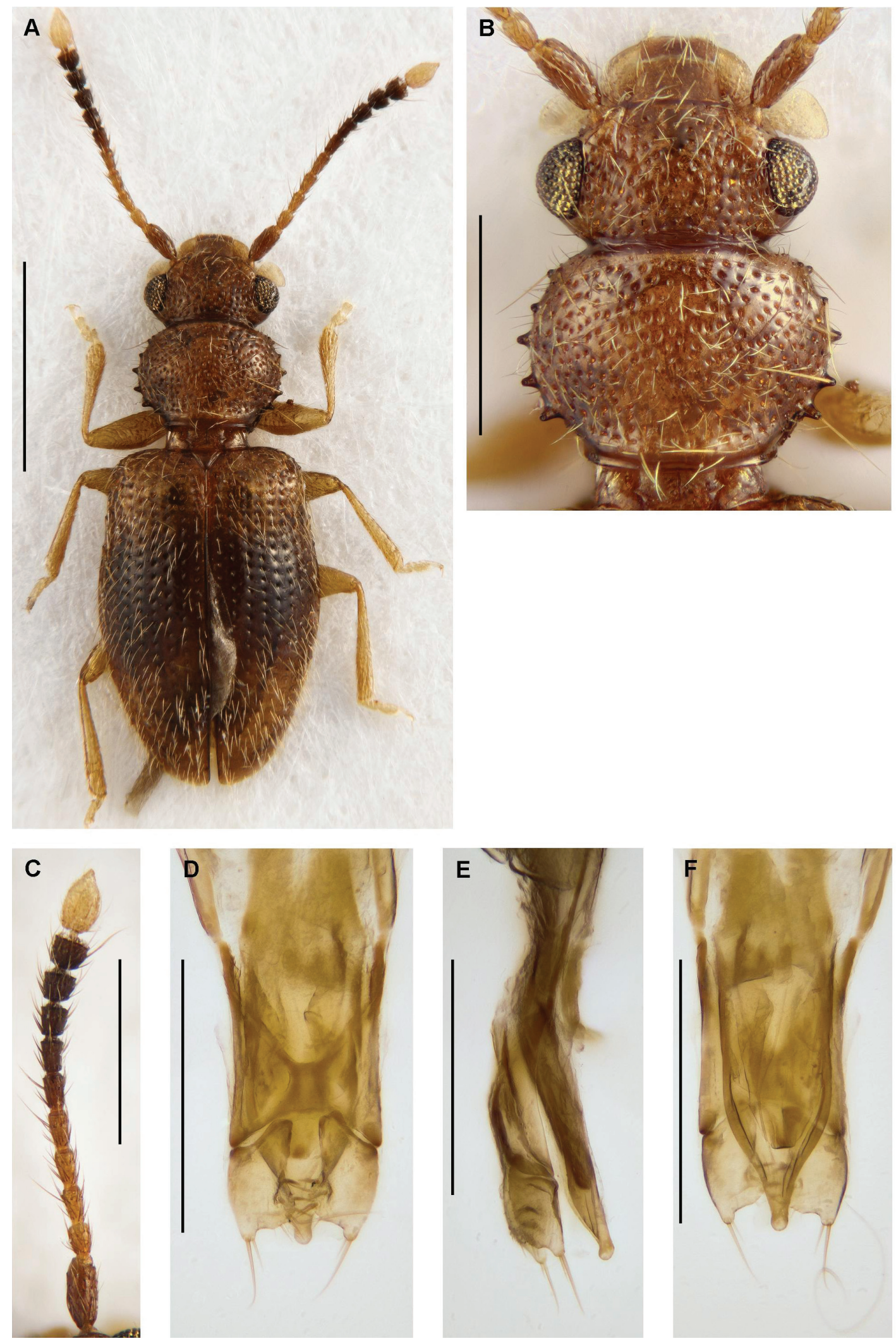

Fig. 6. Psammoecus sinuaticollis sp. nov., holotype. A. Habitus. B. Head and pronotum. C. Right antenna. D-F. Aedeagus $(\mathrm{D}=$ ventral, $\mathrm{E}=$ lateral, $\mathrm{F}=$ dorsal view $)$. Scale lines: $\mathrm{A}=1.0 \mathrm{~mm}, \mathrm{~B}-\mathrm{C}=0.5 \mathrm{~mm}, \mathrm{D}-\mathrm{F}$ $=0.2 \mathrm{~mm}$. 


\section{Paratypes}

$1 \hat{\partial}, 1$, with same data as holotype; antennae of male paratype missing ( $\lesssim$ paratype SMF, $q$ paratype HNHM).

\section{Description of holotype}

Body (as in Fig. 6A). Oval, total length $2.50 \mathrm{~mm}$; testaceous, elytral disk darker brown. Antennae testaceous; antennomere 6 slightly darker; 7-10 dark brown; 11 yellowish white. Legs yellow.

HEAD (as in Fig. 6B). Eyes rounded; temples well defined and rounded, narrowed immediately behind eyes, temple angle $49^{\circ}$; head width $0.64 \mathrm{~mm}$, length $0.36 \mathrm{~mm}$. Punctures on vertex as large as an eye facet, separated by about their diameter, but sometimes contiguous; puncturation increasingly smaller and sparse towards frontoclypeal suture; pubescence composed of semierect setae, directed anteriorly; microsculpture absent. Longitudinal impressions on vertex distinct, curved outwardly, attaining anterior fourth of eyes. Eyes well rounded, $0.19 \mathrm{~mm}$ long, distance of inner margins $0.43 \mathrm{~mm}$. Antennae 1.30 $\mathrm{mm}$ long, attaining anterior fourth of elytra; antennomere proportions of holotype: $2.5: 1.1: 1.3: 1.3$ : $1.3: 1.3: 1.1: 1.0: 1.0: 1.0: 2.3$ (Fig. $6 \mathrm{C}$ ).

Pronotum (as in Fig. 6B). Slightly wider than head, disk convex, rounded, with transverse impression in front of anterior margin; lateral margins evenly curved, widest near middle; width $0.68 \mathrm{~mm}$, length $0.52 \mathrm{~mm}$. Anterior angles with 2 small teeth, lateral margins with 4 teeth whose sizes increase from front to back; posterior angle without tooth. Puncturation and pubescence on pronotal disk as on vertex. Microsculpture absent.

Elytra. Oval, widest somewhat behind middle, length $1.60 \mathrm{~mm}$, combined width $1.05 \mathrm{~mm}$. Rows of punctures on disk a bit more than half as wide as interstices; pubescence composed of semierect setae; strial setae slightly shorter than interstrial setae; microsculpture absent.

Male Genitalia (as in Fig. 6D-E). Parameres with wide basis, lateral face evenly curved, mesal face with rounded projection that bears short, stout spines, apical projection short, bearing one long and one short seta. Lateral faces of median lobe curved, narrowed towards the apex; apex in lateral view widened to form a small knob.

\section{Variation}

The paratypes are of the same body length as the holotype.

Psammoecus personatus Grouvelle, 1919

\section{New records}

MADEIRA: Canhas, 15 Feb. 2002, leg. Lott, 3 specimens (2 BMNH, 1 MKF).

SOUTH AFRICA: Limpopo Province: Arbor Farm, Levubu, 23 Jan. 1998, leg. Müller, 1 specimen (TMSA); Entabeni, 21 Apr. 1976, leg. Endrödy-Younga, 5 specimens (3 TMSA, 2 MKF); Pietersburg, Sep. 1960, leg. Leleup, 1 specimen (TMSA); Soutpansberg, 14 Mar. 1973, leg. Endrödy-Younga, 2 specimens (TMSA). Mpumalanga Province: Barberton, Oct. 1961, leg. Leleup, 1 specimen (TMSA); Nelshoogte, Knuckles Rocks Forest, 11 Feb. 1987, 25 Dec. 1986, leg. Endrödy-Younga, 2 specimens (TMSA).

TANZANIA: Ngare Sero, Usa River, 15 Nov.-31 Dec. 1965, leg. Szunyoghy, 1 specimen (HNHM); Usa River, 24-31 Mar. 1981, leg. Bremer, 1 specimen (HNHM); near Usa River, 20 km east of Arusha, 17 Feb.--6 Mar. 1982, leg. Bremer, 1 q (HNHM). 
UGANDA: Kawanda, 15 Feb.-6 Mar. 1958, leg. P. Whalley, 1 specimen (BMNH). Mbale District, Bubulu, Oct. 1938, leg. Taylor, 1 ${ }^{\prime}, 1$ ㅇ (BMNH).

Psammoecus hacquardi Grouvelle, 1889

\section{New records}

CONGO: Brazzaville, Orstom Park, 19-31 Dec. 1963, leg. Endrödy-Younga, 5 specimens (4 HNHM, 1 MKF); Sibiti, 26-27 Nov. 1963, leg. Endrödy-Younga, 2 specimens (1 HNHM, 1 MKF).

TANZANIA: Daressalam, 15 Apr. 1915, 1 specimen (BMNH); Usambara, Derema, 25 Oct.-21 Nov. 1891, leg. Conradt, 1 ô (ZMHB); Usambara, Nguelo, leg. Heinsen, 1 specimen (ZMHB).

UGANDA: Bundibugyo District, Semliki Forest, 5-12 Feb. 1997, leg. Wagner, 3 specimens (coll. Thomas Wagner); Bwamba County, Jun. 1948, leg. van Someren, 1 q (BMNH).

\section{Psammoecus laetulus Grouvelle, 1914}

Fig. 7A-G

\section{New records}

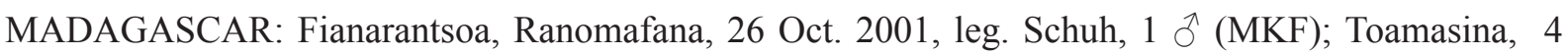
$\mathrm{km}$ SE of Andasibe, $25 \mathrm{~km}$ E of Moramanga, 1 Nov. 2001, leg. Schuh, 1 q (MKF); Toamasina, road to Anosibe an' Ala, road km 18 S of Moramanga, 31 Oct. 2001, leg. Schuh, 1 ㅇ (MKF).

RWANDA: Cyangugu, Nyakabuye, 25 Nov. 1982, leg. Mühle, 1 ô (MKF).

SEYCHELLES: Silhouette, 1908, 1 ○े (BMNH).

SOUTH AFRICA: Eastern Cape Province: Alexandria Forest Station, 3 Apr. \& 6 Dec. 1987, leg. Endrödy-

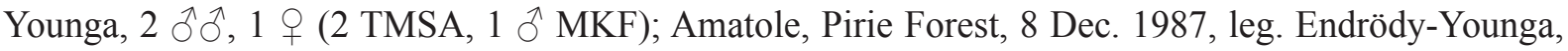
1 specimen (TMSA); Cape Amatole, Tsidenge Forest Station, 22 Nov. 1987, leg. Endrödy-Younga, 1 specimen (TMSA); Berlin, 22 Sep. \& 8 Dec. 1986, leg. Endrödy-Younga, 2 specimens (TMSA); Dwesa Forest Reserve, 17, 26-27 Dec. 1979, leg. Endrödy-Younga, 4 우 (TMSA). KwaZulu Natal Province: Cape Vidal, 24 Jan. 1990, leg. Klimazsewski, 1 specimen (TMSA); Karkloof Forest, 2 Sep. \& 13 Dec. 1989, leg. Endrödy \& Klimaszew, 8 specimens (6 TMSA, 2 MKF); St. Lucia, Mission Rocks, 8-9, 18 Dec. 1975, leg. Endrödy-Younga, 5 specimens (TMSA); Drakensberge, Oqalweni Forest, Oct. 1960, 2 specimens (TMSA); Malvern, Mar. \& Jun. 1897, leg. G.A.K. Marshall, 2 우 (BMNH); Oribi Gorge, Oct. 1961, leg. Leleup, 2 specimens (TMSA); Sodwana Bay National Park, 14-15 Nov. 1996, leg. Uhlig, 2 specimens (ZMHB); Zululand, Dukuduku Forest Station, 4 Apr. 1974, leg. Endrödy-Younga,

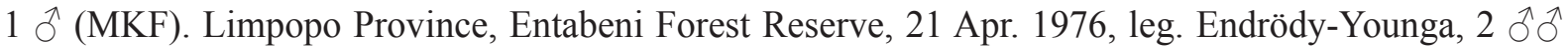
(TMSA); Mariepskop Forest, Aug. 1960, leg. Leleup, 1 specimen; 6 May. 1981, leg. Endrödy-Younga, 1 specimen (TMSA); Soutpansberg, 1 (TMSA); Soutpansberg, Hanglip, 14 Mar. 1973, leg. EndrödyYounga, 1 specimen (TMSA). Mpumalanga Province: Hazyview, 3 Apr. 1990, leg. Endrödy-Younga, 2

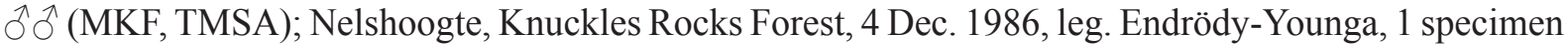
(TMSA); Barberton, Oct. 1961, leg. Leleup, 1 specimen (TMSA). Ostkap, Port St. John, Oct. 1923, Jul. \& Jan. 1924, leg. Turner, 4 specimens.

\section{Remarks and comparative notes}

Numerous specimens from the Ditsong National Museum of Natural History (Pretoria), were, at first sight, considered to belong to one, or even several, new species. Examination of the aedeagi revealed, however, no differences sufficient for a separation of these forms from P. laetulus (Fig. 7E-G). Unless 

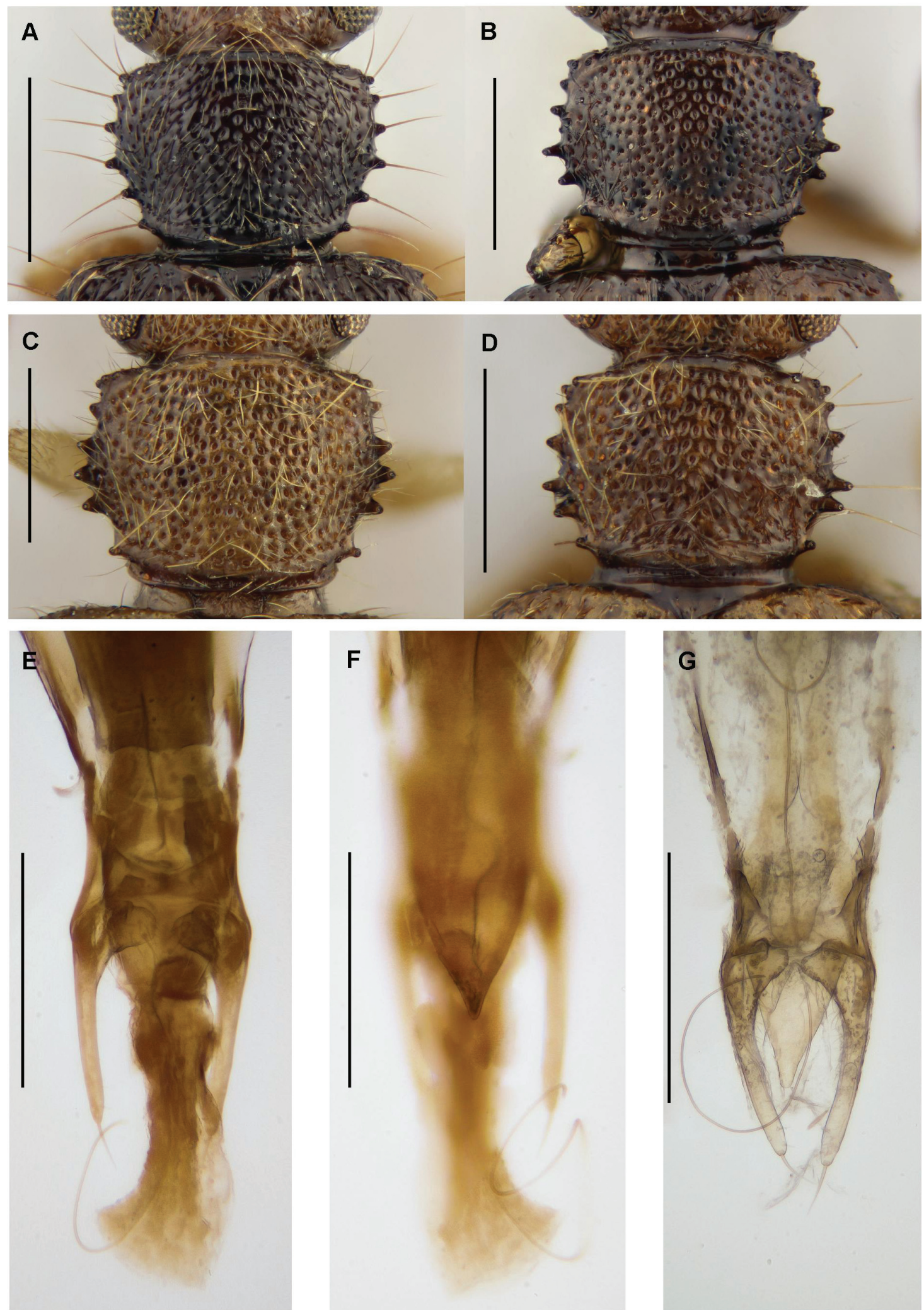

Fig. 7. Psammoecus laetulus Grouvelle, 1914. Pronotum of specimens from A. Mahe, Seychelles. B. Cape Province, South Africa. C. KwaZulu-Natal, South Africa. D. Mpumalanga, South Africa. E-F. Aedeagus of specimen from Mahe, Seychelles $(\mathrm{E}=$ dorsal, $\mathrm{F}=$ ventral view). G. Aedeagus of specimen from Mpumalanga, South Africa, dorsal view. Scale lines: $A-D=0.5 \mathrm{~mm}, \mathrm{E}-\mathrm{G}=0.2 \mathrm{~mm}$. 
reliable diagnostic differences dictate otherwise, it is considered appropriate to treat $P$. laetulus as a species that shows significant variability. Fig. 7A-D shows the pronota of specimens from different locations to illustrate individual variations.

One of the Malvern specimens (KwaZulu Natal Province of South Africa) collected by Marshall in 1897 (BMNH) bears a type label by A. Grouvelle, with the name 'Psammoecus distinctus'. Since no description of a taxon with that name is available, the name is to be considered a manuscript name.

Psammoecus parallelus Grouvelle, 1919

\section{New records}

CONGO: Brazzaville, Kindamba, Méya, Louolo River, 12 Feb. 1963, leg. Endrödy-Younga, 1 specimen (HNHM); Orstom Park, 21 Dec. 1963, leg. Endrödy-Younga, 1 specimen (HNHM).

GHANA: Ashanti, Khumasi, Nhiasu, 5 Feb. \& 10 Dec. 1967, leg. Endrödy-Younga, 2 specimens (HNHM); Kwadaso, 25 Feb.-28 Jul. 1969, leg. Endrödy-Younga, 9 specimens (7 HNHM, 2 MKF). Northern Region, Banda-Nkwanta, 23-26 Aug. 1965, leg. Endrödy-Younga, 1 specimen (HNHM).

SOUTH AFRICA: 15 miles SW of Johannesburg, 28 Dec. 1971, 1 specimen (BMNH). KwaZulu Natal Province: Karkloof Forest, 13 Dec. 1989, leg. Endrödy \& Klimaszew, 4 specimens (TMSA); Pondoland, Fort St. John, Sep. 1923, leg. R.E. Turner, 1 specimen (BMNH).

TANZANIA: Arusha, Usa River, 25 Sep. 1965, leg. Szunyoghy, 1 specimen (HNHM); Mizimu, Mwanihana, 3-6 Aug. 2010, leg. Smith \& Takano, 1 specimen (BMNH); Morogoro, Feb. 1970, leg. T. Pócs, 1 specimen (HNHM).

UGANDA: District Masindi, Budongo Forest, Sonso, 5-15 Jan. 1997, leg. Th. Wagner, 1 q (coll. Thomas Wagner); Kawanda, 15 Feb.-6 Mar. 1958, leg. Whalley, 1 specimen (BMNH).

\section{Psammoecus leleupi Karner, 2012}

\section{New records}

ANGOLA: Cuanza Norte, Salazar, 9-15 Mar. 1972, 10^, 3 우 (BMNH).

CAMEROON: 1916, leg. Schwab, 3 + + (BMNH).

CONGO: Brazzaville, Orstom Park, 31 Dec. 1963, leg. Endrödy-Younga, 1 q (HNHM); Sibiti, 25 Nov. 1963, leg. Endrödy-Younga, 2 specimens (HNHM).

GABON: Ogooué-Ivindo Province, Makokou, Apr., May 1971, leg. Mateu, 2 specimens (MHNG).

GHANA: Ashanti, Jamasi, 15 Sep. 1969, leg. Endrödy-Younga, 1 ð (HNHM); Kwadaso, 22 May 1969, leg. Endrödy-Younga, 1 ô (HNHM). Northern Region, Banda-Nkwanta, 8 Sep. 1965, leg. EndrödyYounga, 1 \& (HNHM).

GUINEA: Macenta Prefecture, Seredou, 4-8 Apr. 1975, leg. Zott, 3 specimens (ZMHB).

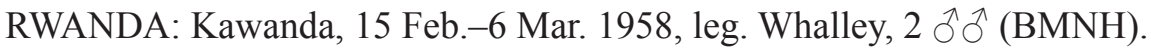

UGANDA: Kabarole, Kibale National Park, 25 km SE of Fort Portal, Kanyawara, 26 Jul.-22 Aug. 1998, leg. Schmidt, 1 (MKF). 


\section{Remarks}

The specimen from Cameroon bears a handwritten label 'Psammoechus orbicollis t. Gr. Grouv.', not in Grouvelle's hand. This is to be considered a manuscript name, since no description of a taxon with that name is available.

Psammoecus luchti Karner, 2012

\section{New record}

CAMEROON: Northwest Province, Bamenda, Nov. 1981, leg. Cho Chi Ignatius. 1 o (HNHM).

Psammoecus marginicollis Grouvelle, 1908

\section{New records}

KENYA: Chyulu Hills, Jun. 1938, 1 ô (TMSA).

UGANDA: Masindi District, Budongo Forest, 12-29 Jan. 1997, leg. Göllner, 4 specimens (ZMHB); Mbale District, Butandinga, Dec. 1938, leg. Taylor, 1 đ̊ (BMNH).

\section{Psammoecus longicornis Schaufuss, 1872}

\section{New record}

SOUTH AFRICA: Mpumalanga Province: Nelshoogte Pass, 10 Feb. 1987, leg. Endrödy-Younga, 11 specimens (9 TMSA, 2 MKF).

Psammoecus trimaculatus Motschulsky, 1858

\section{New records}

MAURITIUS: Jul. 1931, leg. Wigglesworth, 1 specimen (BMNH).

RÉUNION: Bras des Chévrettes, 16-19 Dec. 1991, leg. Janék, 8 specimens (ZMHB).

SOUTH AFRICA: KwaZulu Natal Province: Dukuduku Forest Station, 4 Apr. 1974, leg. EndrödyYounga, 2 specimens (TMSA); Magudu, 4 Jan. 2009, leg. Müller, 6 specimens (5 TMSA, 1 MKF); Mtubatuba, 4 Apr. 1974, leg. Endrödy-Younga, 1 specimen (TMSA); St. Lucia, Mission Rocks, 3-18 Dec. 1975, leg. Endrödy-Younga, 9 specimens (7 TMSA, 2 MKF); Zululand, Empageni, 5 Mar. 1977, leg. P.E. Reavel, 2 specimens (TMSA). Ostkap, Port St. Johns, Silaka, 2 Dec. 1987, leg. EndrödyYounga, 2 specimens (TMSA).

TANZANIA: Usa River, 1965, leg. J. Szunyoghy, 1 specimen (HNHM).

UGANDA: Bukalada, 3 May 1926, leg. Hargreaves, 1 specimen (BMNH); District Masindi, Budongo Forest, N. Sonso, 15-25 Jan. 1997, leg. Wagner, 1 ô, 1 (coll. Thomas Wagner); Kabarole, Kibale Nat. Park, 25 km SE of Fort Portal, Kanyawara, 26 Jul.-22 Aug. 1998, leg. L. Schmidt, 1 specimen (MKF).

Psammoecus simoni Grouvelle, 1892

\section{New records}

RÉUNION : Bourbier, 20 Dec. 1991, leg. Janék, 3 specimens (ZMHB); Bras des Chévrettes, 16-19 Dec. 1991, leg. Janék, 47 specimens (ZMHB); Plaine des Palmistes, Petite Plaine, 27 Dec. 1991, leg. Janék, 1 
specimen (ZMHB); Ravine de St. Gilles, Bassin Cormoran, 13-14 Jan. \& 22-23 Jan. 1992, leg. Janék, 2 specimens (ZMHB); Ravine de St. Gilles, Bassin des Algrettes, 13-14 Jan. 1992, leg. Janék, 1 specimen (ZMHB); Saint Paul, 29 Dec. 1991-1 Jan. 1992, leg. Janék, 3 specimens (ZMHB); Saint Paul, Grand Étang, 29 Dec. 1991-1 Jan. 1992, leg. Janék, 2 specimens (ZMHB); Saint Paul, Ravine de Bernica, 29 Dec. 1991-1 Jan. 1992, leg. Janék, 1 specimen (ZMHB).

SEYCHELLES: Mahé, 14-26 Arp. 1978, leg. Münch, 1 specimen (HNHM).

\section{Key to the African species of Psammoecus Latreille, 1829}

Psammoecus laetulus Grouvelle, 1914 appears in couplets 12 and 15 of the determination key by intent, reflecting the high morphological variability that is observed in this species.

1 Lateral margins of pronotum without teeth; only anterior and posterior groups of small teeth present

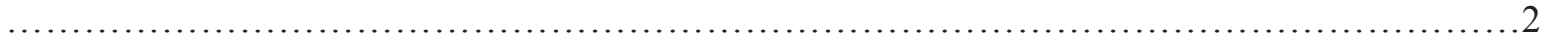

- Lateral margins of pronotum with various number of large or small teeth .........................

$23^{\text {rd }}$ antennomere shorter than $2^{\text {nd. }}$, elytral rows of punctures narrower than interstices

lateralis (Grouvelle, 1899)

$-3^{\text {rd }}$ antennomere longer than $2^{\text {nd; }}$, elytral rows of punctures somewhat wider than interstices longicornis Schaufuss, 1872

3 Body length $3.40-4.20 \mathrm{~mm}$; lateral margins of pronotum with very small teeth; $1^{\text {st }}$ antennomere more

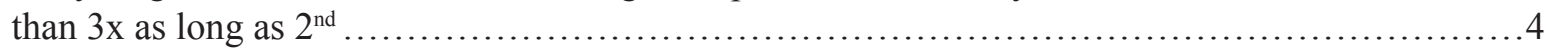

- Body length not more than $3.30 \mathrm{~mm}$; lateral margins of pronotum with distinct teeth, $1^{\text {st }}$ antennomere less than $3 \mathrm{x}$ as long as $2^{\text {nd }}$

4 Antennomeres 3 - 10 wide, stout (Fig. 5A); median lobe of aedeagus wide, abruptly narrowed towards apex (Fig. 5B) grandis Grouvelle, 1908

- Antennomeres 3-10 slender (Fig. 4D); median lobe of aedeagus slender, gradually narrowed towards apex (Fig. 4G) ..procerus sp. nov.

5 Interstices of lateral striae of elytra with large denticles; pronotum with very long lateral teeth .spinosus Grouvelle, 1882

- Interstices of lateral striae of elytra with very small denticles or small tubercles .................6

6 Anterior angle of pronotum without denticle (Fig. 6B) ........................sinuaticollis sp. nov.

- Anterior angle of pronotum with distinct denticle ............................................ 7

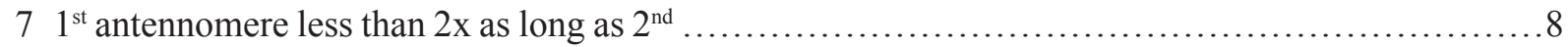

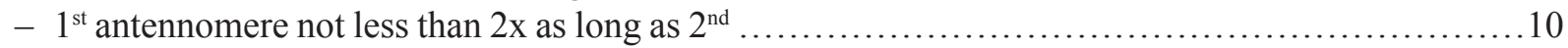

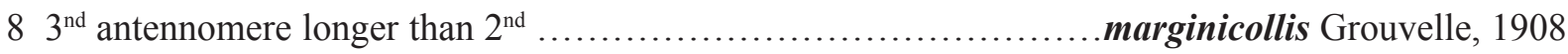

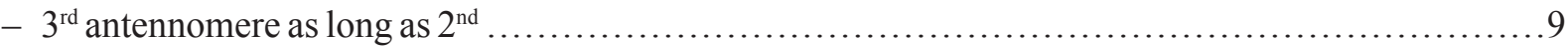

9 Striae on elytral disk narrower than interstices; lateral teeth of pronotum with narrow bases ..personatus Grouvelle, 1919

- Striae on elytral disk wider than interstices, lateral teeth of pronotum with wide bases .leleupi Karner, 2012

10 Maximum pronotal width near middle (excluding lateral teeth) .............................11

- Maximum pronotal width in anterior third (excluding lateral teeth) ........................... 15 


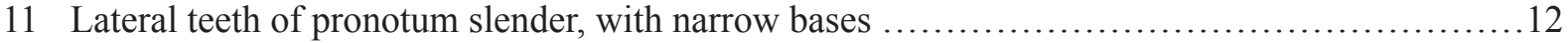

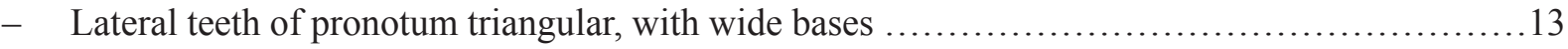

12 Reticulate microsculpture on disk of pronotum ......................hacquardi Grouvelle, 1889

- Microsculpture on disk of pronotum absent ............................laetulus Grouvelle, 1914

13 Elytral striae distinctly wider than interstices; humeral swelling, a transverse band in the middle of elytra, elytral suture along posterior two thirds and elytral apex dark; parameres short, stout, fused with basal piece .................................................simoni Grouvelle, 1892

- Elytrae with round macula and darkened suture near apex; parameres abruptly narrowed towards

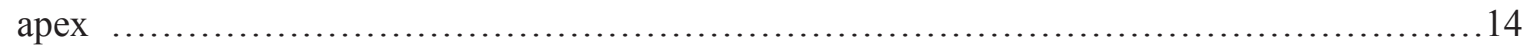

14 Elytral striae slightly wider than interstices; median lobe of aedeagus slender, evenly narrowed towards apex (Fig. 3A) .............................................luchti Karner, 2012

- Elytral striae narrower than interstices, median lobe of aedeagus wide, abruptly narrowed towards apex (Fig. 2E) .................................................nyakabuyensis sp. nov.

15 Elytrae with dark humeral area, wide dark band across middle and dark suture near apex; or only with darkened band behind middle, sometimes interrupted near suture; parameres gradually narrowed towards apex ................................................laetulus Grouvelle, 1914

- Elytral striae narrower or only slightly wider than interstices; parameres distinctly separated from

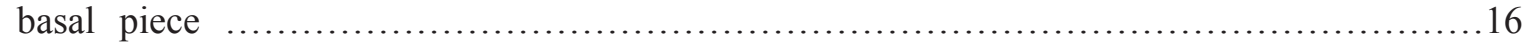

16 Lateral margin of pronotum with 4 distinct teeth between small posterior tooth and anterior group of small teeth .............................................trimaculatus Motschulsky, 1858

- Lateral margin of pronotum with 5 distinct teeth between small posterior tooth and anterior group of small teeth parallelus Grouvelle, 1919

\section{Discussion}

Taking into account the considerable differences in the appearance of African species, it seems likely that Psammoecus is composed of several distinct species groups. However, given the high diversity of Psammoecus in the Oriental and Australian regions and the lack of revisionary work on species from these regions - with the exception of the revisions of Indian Psammoecus by Pal (1985) and Japanese Psammoecus by Yoshida \& Hirowatari (2014) - it seems as yet premature to aim at establishing even a 'working taxonomy' on the genus or subgenus level. Hence, future studies will show whether a further subdivision of the genus Psammoecus is justified.

\section{Acknowledgements}

For the loan of specimens the author is indebted to Ruth Müller (Ditsong National Museum of Natural History, Pretoria), Roger Booth (The Natural History Museum, London), Giulio Cuccodoro (Muséum d'Histoire Naturelle, Geneva), Ottó Merkl (Termeszettudomanyi Muzeum, Budapest), Manfred Uhlig (Museum für Naturkunde der Humboldt-Universität, Berlin), and Thomas Wagner (Koblenz).

\section{References}

Karner M. 2012. A revision of African Psammoecus (Coleoptera, Silvanidae) and descriptions of two new species from the collection of the Musée royal de l'Afrique centrale. European Journal of Taxonomy 17: 1-31. http://dx.doi.org/10.5852/ejt.2012.17 
Pal T.K. 1985. A revision of Indian Psammoecus Latreille (Coleoptera, Silvanidae). Records of the Zoological Survey of India, Miscellaneous Publication, Occasional Paper 71, Zoological Survey of India, New Alipore.

Steedman H.F. 1958. Dimethyl hydantoin formaldehyde: A new water-soluble resin for use as a mounting medium. Quarterly Journal of Microscopical Sciences 99: 451-452.

Yoshida T. \& Hirowatari T. 2014. A revision of Japanese species of the genus Psammoecus Latreille (Coleoptera, Silvanidae). ZooKeys 403: 15-45. http://dx.doi.org/10.3897/zookeys.403.7145

Manuscript received: 23 April 2014

Manuscript accepted: 10 June 2014

Published on: 4 July 2014

Topic editor: Koen Martens

Desk editor: Kristiaan Hoedemakers

Printed versions of all papers are also deposited in the libraries of the institutes that are members of the EJT consortium: Muséum National d'Histoire Naturelle, Paris, France; Botanic Garden Meise, Belgium; Royal Museum for Central Africa, Tervuren, Belgium; Natural History Museum, London, United Kingdom; Royal Belgian Institute of Natural Sciences, Brussels, Belgium; Natural History Museum of Denmark, Copenhagen, Denmark. 